
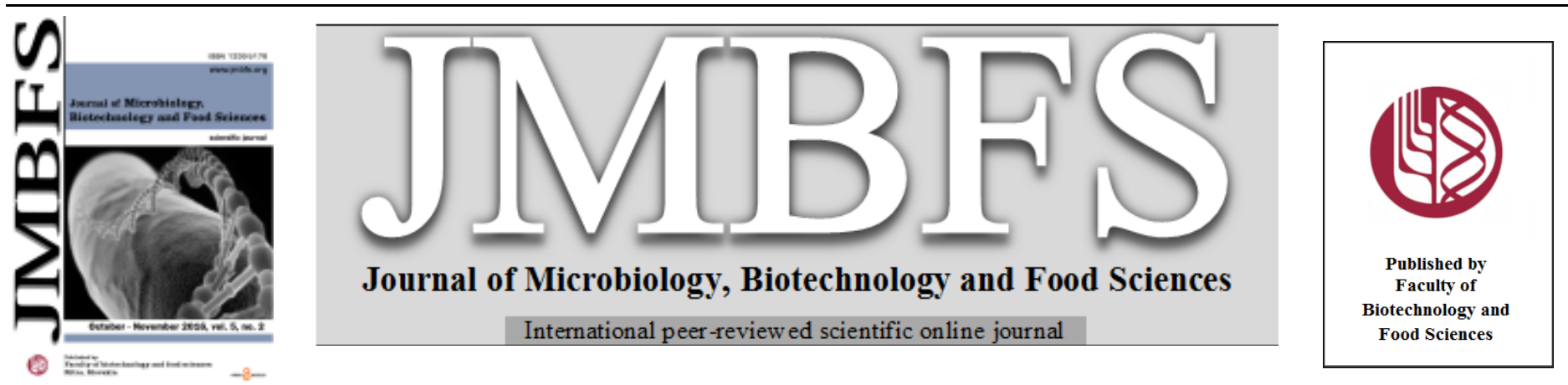

\title{
STUDY OF BIOSURFACTANT PRODUCING BACTERIA AND PRELIMINARY CHARACTERIZATION OF BIOSURFACTNAT PRODUCED BY BACILLUS SPECIES ISOLATED FROM PETROLEUM CONTAMINATED SOIL
}

\author{
Dhaval Patel $^{1}$, M. Nataraj $^{* 2}$ \\ Address(es): Dhaval Patel, \\ ${ }^{1}$ B.R.D. School of Biosciences, Sardar Patel University, Vallabh vidyanagar- 388 120, Dist: Khaira, Gujarat (India). \\ ${ }^{2}$ B.R.D. School of Biosciences, Sardar Patel University, Vallabh vidyanagar- 388 120, Dist: Khaira, Gujarat (India), +91-2692-234412 extension-303. \\ *Corresponding author: nattusamy@yahoo.com \\ doi: 10.15414/jmbfs.2016.6.2.823-827 \\ ARTICLE INFO \\ Received 5. 11. 2014 \\ Revised 25. 4. 2016 \\ Accepted 12. 7. 2016 \\ Published 3. 10. 2016 \\ Short communication \\ open $\partial$ access

\begin{abstract}
Chemically synthesized amphiphilic molecules like surfactants are used for variety of purposes, but they are costly and less or nondegradable and may be toxic once released in the environment. Microbially produced biosurfactants are better alternatives of chemical surfactants as they are stable as well as easily biodegradable and also due to structural and functional similarities with chemical surfactants. The aim of this study was to isolate and characterize biosurfactant producing bacteria from oil contaminated sample (garage soil, Anand, Gujarat). Thirty bacterial cultures were isolated on the basis of differences in their colony characters. To confirm and compare the efficiency of biosurfactant production, hemolytic activity and reduction in surface tension was analyzed. Biochemical and morphological tests identified bacterial isolate $\mathrm{C} 5 \mathrm{C}$ (Gram positive rods arranged in short chains) as Bacillus species. Optimum pH and temperature for biosurfactant production were 5 and $30^{\circ} \mathrm{C}$, respectively. It produced $3.12 \mathrm{~g} / \mathrm{l}$ of biosurfactant in MSM medium with $1 \%$ diesel as carbon source. Biosurfactant produced by $\mathrm{C} 5 \mathrm{C}$ contains lipid. No carbohydrates or amino acid component was detected on TLC plate.
\end{abstract}

Keywords: Bacillus species, Biosurfactant, Biochemical characterization, TLC, Mass of Drop

\section{INTRODUCTION}

Reduction in surface tension is aided by variety of surfactants. Commercially used surfactants are produced chemically as derivatives from petroleum products (Ali et al., 2013). Such surfactants are used in variety of applications like foaming agent, detergents, emulsifiers, solubilizer, in wetting and spreading etc. because of their amphiphilc nature (Ali $\boldsymbol{e t}$ al., 2013). They lower interfacial tension by accumulating at interfaces and micelles formation (Rufino et al., 2014). Major drawback of using the chemical surfactants is their cost and undesirable residues which are difficult to dispose off and degrade leading to environmental pollution (Batista et al., 2006; Aparna et al., 2012; Marchant and Banath, 2012; Ali et al., 2013). Therefore there is continuous search for eco-friendly biosurfactants to replace chemical surfactants.

Biosurfactants are better alternatives because they are easily biodegradable (Rufino et al., 2014). They are structurally and functionally similar to chemical surfactants and synthesized both by bacteria and fungi including yeast (Satpute et al., 2010; Marchant and Banath, 2012; Ali et al., 2013). They are having hydrophobic and hydrophilic parts in their structure. They are produced extracellularly or as part of cell structure (Sneha $\boldsymbol{e t}$ al., 2012). In recent years, development of biosurfactant technology has taken paramount importance due to their biocompatibility, low toxicity, higher biodegradability and higher stability under extreme conditions like $\mathrm{pH}$ and temperature (Sadat $\boldsymbol{e t}$ al., 2013; Kim $\boldsymbol{e}$ al., 2004; Rufino et al., 2014). Biosurfactants are so diverse chemically that they can be used in medical field, cosmetic industries, for environmental applications as well as other processes like enhanced oil recovery process. Despite such advantages and applications, biosurfactants are not exploited much because of limited knowledge regarding production condition and extent to which organism produces this substances. Present study was undertaken to screen bacteria isolated from oil spilled region (garage soil) for biosurfactant production and their characterization.

\section{MATERIAL AND METHODS}

\section{Sampling area}

For isolation of biosurfactant producing bacteria soil samples were collected from different garages around Anand (Gujarat, India). The soil samples from contaminated sites were collected in sterile containers and brought to the laboratory for further studies.

\section{Enrichment and isolation of bacterial cultures}

$5.0 \mathrm{gm}$ of soil samples were suspended by thorough mixing in $100 \mathrm{ml}$ phosphate buffer saline (PBS). After settling of soil debris $5 \mathrm{ml}$ supernatant was transferred to $50 \mathrm{ml}$ of Bushnell-Haas (BH) Medium $\left[\mathrm{MgSO}_{4} 0.2 \mathrm{~g} / \mathrm{L}, \mathrm{CaCl}_{2} 0.02 \mathrm{~g} / \mathrm{L}\right.$, $\left.\mathrm{KH}_{2} \mathrm{PO}_{4} 1.0 \mathrm{~g} / \mathrm{L}, \mathrm{K}_{2} \mathrm{HPO}_{4} 1.0 \mathrm{~g} / \mathrm{L}, \mathrm{NH}_{4} \mathrm{NO}_{3} 1.0 \mathrm{~g} / \mathrm{L}, \mathrm{FeCl}_{3} 0.05 \mathrm{~g} / \mathrm{L}\right]$ with $1 \%$ diesel as sole source of carbon and incubated at $25^{\circ} \mathrm{C}, 200 \mathrm{rpm}$ for 4 days (Batista et al., 2006). After incubation $1 \mathrm{ml}$ of sample was transferred to fresh BH medium (with $1 \%$ diesel) and incubated again as stated above. After three cycle of enrichment, loop full of culture was streaked on BH agar medium with $1 \%$ diesel and incubated at $37^{\circ} \mathrm{C}$ for 1 week. Colonies with different morphology were selected and transferred on nutrient agar slant $(\mathrm{pH} 7.0 \pm 0.2)$ and stored at $4^{\circ} \mathrm{C}$

\section{Hemolytic activity of isolates}

Hemolytic activity is considered to be good and easy criteria to screen out biosurfactant producers. For that fresh single colonies of isolated cultures were taken and streaked on blood agar plates. Plates were incubated for 24 to $48 \mathrm{hrs}$ at $37^{\circ} \mathrm{C}$. The plates were visually inspected for zone of clearance (hemolysis) around colonies. Hemolysis was designated as alpha $(\alpha)$, beta $(\beta)$ and gamma $(\gamma)$ hemolytic activity and was used as qualitative method for selection of better producer of biosurfactant (Satpute $\boldsymbol{e t}$ al., 2010; Ali et al., 2013; Varjani et al., 2014). Five cultures were selected on the basis of the hemolytic activity for further study. 


\section{Identification of bacterial culture}

The selected bacterial isolates were characterized by morphological/microscopic and biochemical tests such as Gram staining, Methyl Red (MR test), Voges Proskauer (VP test), Citrate utilization test, Nitrate reduction test, $\mathrm{H}_{2} \mathrm{~S}$ production test, Gelatine hydrolysis test, Glucose and Sucrose fermentation test and catalase test. Cultures were also subjected to Triple Sugar Ion (TSI) test. Results from biochemical analysis were used to find the closest match with known bacteria genus and to assign the bacterial signature according to Bergey's manual (Nasr et al., 2009; Anandraj and Thivkaran, 2010; Ali et al., 2013).

\section{Quantitative measurement of reduction in surface tension}

Reduction in surface tension was analyzed from broth medium. For that, bacterial cultures were activated in LB broth for $24 \mathrm{hrs}$ at $37^{\circ} \mathrm{C}$. After activation $1 \mathrm{ml}$ inoculums with 1.00 O.D. $600 \mathrm{~nm}$ cells were transferred to the $100 \mathrm{ml} \mathrm{BH}$ medium with $2 \%$ diesel as carbon source. Broth was agitated at $200 \mathrm{rpm}$ for one week for growth and biosurfactant production. Surface tension was measured by drop weight method described by William Burns Tucker (1938). It is second mos precise and easy method for determination of surface tension. Cells were removed by centrifugation at $5000 \mathrm{rpm}$ for $15 \mathrm{~min}$ and supernatant was collected. Cell free supernatant was poured in a burette which was attached to a rubber tube on one side and glass tube of $3 \mathrm{~mm}$ diameter at another side. An empty preweighed beaker was placed under burette and supernatant was released slowly drop by drop. 50 drops were poured in to the beaker and it was weighed to determine the weight of 50 drops. Mass of one drop was calculated by using following formula (Ramesh et al., 2011).

$$
\begin{aligned}
& \text { Mass of Drop }(M) \\
& =\frac{(\text { Sample }+ \text { Beaker weight })-(\text { Weight of empty Beaker })}{\text { Number of drops }}
\end{aligned}
$$

Surface tension and surface activity was measured by following formula.

$$
\text { Surface tension }=\frac{M g \times 10^{-3} \times n M^{-1}}{\pi r}
$$

Where, "M" is mass of one drop, "g" is gravity and " $\mathrm{g}$ " is radius of glass tube. Value of Surface tension was used to calculate surface activity.

Surface activity $=$ Surface tension of Uninoculated medium

Optimization of growth medium - Surface tension of Supernatant

\section{pH optimization}

The initial $\mathrm{pH}$ value of them MSM medium with $1 \%$ diesel was adjusted over a range of 2 to 9 and media were sterilized in triplicates. Media were inoculated with $1 \% \mathrm{v} / \mathrm{v}$ inoculum and incubated for seven days at $120 \mathrm{rpm}$. After incubation period, cell free supernatants (crude biosurfactant) were obtained by centrifugation (8000 rpm for $15 \mathrm{~min}$ ) and E24\% was determined for samples of each $\mathrm{pH}$ according to method suggested by Chandran and Das (2011). For E24\% $1 \mathrm{ml}$ of cell free supernatant was added in test tube containing $1 \mathrm{ml}$ diesel followed by through mixing for $1 \mathrm{~min}$ by vortex. After $24 \mathrm{hrs}$ emulsification index was calculated as

$$
E 24 \%=\frac{\text { Hight of Emulsuion Formed }}{\text { Total Hight of Solution }} \times 100
$$

\section{Temperature optimization}

$100 \mathrm{ml}$ of MSM medium with $1 \%$ Diesel ( $\mathrm{pH} 7$ ) sterilized at $121 \mathrm{psi}$ for $15 \mathrm{~min}$ After sterilization, $1 \mathrm{ml}$ of activated cells with 1.00 O.D.600nm were transferred to medium under aseptic condition and incubated at $120 \mathrm{rpm}$ for seven days at different temperatures; 30, 40, 50, 60, 70, 80, 90 and $100^{\circ} \mathrm{C}$. Experiment was carried out in triplicates. After incubation E24\% was calculated from cell free broth for each flask

\section{Inoculum development:}

For inoculum preparation, single colony of $\mathrm{C} 5 \mathrm{C}$ isolate was aseptically transferred to fresh sterile Luria-Bretani broth and incubated at $37^{\circ} \mathrm{C}$ until its O.D. 600 reaches to 1.00 .

\section{Production and extraction of biosurfactant:}

The production of biosurfactant was carried out in MSM medium with $1 \%$ diesel 1.00 O.D.600nm cells were aseptically transferred to production medium with optimized $\mathrm{pH}$. After inoculation medium was incubated for seven days at optimized temperature. Biosurfactant was extracted by solvent extraction method (Chander et al., 2012). In order to precipitate lipids and proteins, $6 \mathrm{~N} \mathrm{HCl}$ was added in supernatant to bring $\mathrm{pH} 2$ and kept overnight at $4^{\circ} \mathrm{C}$. White colour precipitates were collected by centrifugation at $10,000 \mathrm{rpm}$ for $20 \mathrm{~min}$. Further extraction was carried out by adding $10 \mathrm{ml}$ chloroform: methanol $(2: 1 \mathrm{v} / \mathrm{v})$ to the precipitated pellet which was dissolve in $10 \mathrm{ml}$ of distilled water. Phases were allowed to separate. Organic phase was collected in pre-weighted petriplate and kept at room temperature for evaporation. After complete evaporation, petriplate was weighted and produced biosurfactant was calculated as

\section{Biosurfactant Production \\ = Weight of petriplate after drying - Weight of empty petriplate}

Characterization of biosurfactant by Thin Layer Chromatography [TLC]

To identify the component parts of biosurfactant silica gel plates were used. A spot of crude biosurfactant was placed on silica gel plate. The biosurfactant was separated on plate using following four systems. System 1 Petroleum etherdiethyl ether-acetic acid (80:20:1) for neutral lipid. System 2 Chloroformmethanol-water (65:52:4) for polar lipid. System $3 n$ butanol-acetic acid-water (4:1:1) for amino acid. System 4 ethyl acetate-acetic acid-methanol-water $(12: 3: 3: 2)$ for carbohydrates. After development visualization was carried out for separated components. Lipid was visualized by placing the plates in closed jar saturated with iodine vapour which gave yellow colour spots. Amino acids were visualized by using ninhydrin reagent followed by heating at $90^{\circ} \mathrm{C}$ for $15 \mathrm{~min}$ which gives red or purple colour. Carbohydrate was visualized by detecting red colour spot on spraying with alpha-naphthol-sulphuric acid solution (Yin et al., 2009).

\section{RESULTS AND DISCUSSION}

\section{Isolation and screening of bacteria}

Thirty bacteria with different colony characteristics were isolated from three soil sample each from various location of a Garage by following three successful cycles of enrichment. Twenty one isolates were found to be Gram positive and rest of nine were Gram negative in gram reaction.

\section{Hemolytic activity and biochemical characterization of bacteria}

All isolates were streaked on the blood agar plates. The hemolytic activity was observed in all thirty isolated strain, results showed alpha hemolytic activity by strain SD2-B, SO2-A , C1C, C6C, C3N, C6N and M-B, beta hemolytic activity by SD1-A, SD1-B, SD1-C, SD1-D, SO1-A, SO1-B, SO2-B, M-A, H-A, H-B, H-C, $\mathrm{C} 2 \mathrm{C}, \mathrm{C} 3 \mathrm{C}, \mathrm{C} 4 \mathrm{C}, \mathrm{C} 5 \mathrm{C}, \mathrm{C} 7 \mathrm{C}, \mathrm{C} 2 \mathrm{~N}$ and $\mathrm{C} 4 \mathrm{~N}$ and hemolytic activity gamma was indicated by SO2-A, H-D, C1N, C5N, C6N and C7N (Table-1). Hemolytic activity is qualitative measurement of biosurfactant ability of cultures (Satpute et al., 2010). Hemolytic zone on blood agar plate have linear relation with the concentration of biosurfactant produced by bacteria (Youssef $\boldsymbol{e t}$ al., 2014). Therefore out of thirty bacterial cultures five isolates SD1, SO1-B, SD2-A SO2-B and C5C were selected for further study on the basis of hemolytic zone on blood agar plates and characterized biochemically (Table-1). 
Table 1 Microscopic and biochemical characterization of selected cultures

\begin{tabular}{|c|c|c|c|c|c|}
\hline \multirow{2}{*}{ Test } & \multicolumn{5}{|c|}{ Cultures } \\
\hline & $\mathrm{C5C}$ & SD1-A & S01-B & SD2-A & SO2-B \\
\hline Gram Reaction & Positive & Positive & Negative & Positive & Negative \\
\hline Blood Hemolysis & $\mathrm{B}$ & $\beta$ & $\beta$ & $\gamma$ & $\beta$ \\
\hline Zone of hemolysis $^{*}$ & ++++ & +++ & +++ & +++ & +++ \\
\hline Methyl Red test & Negative & Positive & Negative & Positive & Positive \\
\hline Voges Proskauer Test & Positive & Positive & Positive & Negative & Negative \\
\hline Citrate Utilization & Positive & Negative & Negative & Negative & Positive \\
\hline Catalase test & Negative & Positive & Positive & Positive & Positive \\
\hline Gelatine liquefaction & Negative & Negative & Negative & Positive & Positive \\
\hline Nitrate reduction & Positive & Positive & Positive & Positive & Positive \\
\hline $\mathrm{H}_{2} \mathrm{~S}$ Production & Negative & Negative & Positive & Negative & Positive \\
\hline Starch Utilization & Positive & Negative & Negative & Positive & Positive \\
\hline Sucrose fermentation & Negative & Positive & Positive & Positive & Positive \\
\hline Glucose fermentation & Positive & Positive & Positive & Positive & Positive \\
\hline TSI $^{* *}$ & A/Ak/-/+ & A/Ak/-/- & $\mathbf{A k} / \mathbf{A} /+/+$ & Ak/Ak/-/- & $\mathbf{A k} / \mathbf{A} /+/+$ \\
\hline
\end{tabular}

$\mathrm{H}_{2}$ Sproduction/Gas production

Results showed that C5C was positive for Voges Proskauer test (VP test), citrate utilization test, nitrate reduction test, starch hydrolysis test and glucose fermentation test (Table-1). These data are quit comparable with results of Bacillus (Aparna et al., 2012). Figure 1 showed the morphology of C5C by Gram's staining. SD2-A was able to ferment glucose and sucrose and showed starch hydrolysis. It gave positive result for methyl red test (MR test), but negative for VP test and citrate utilization test. All other positive tests included catalase test, gelatine liquification, nitrate reduction and $\mathrm{H}_{2} \mathrm{~S}$ production. Triple Sugar Ion slant (TSI) gave alkaline reaction at both slant and butt region with neither $\mathrm{H}_{2} \mathrm{~S}$ nor gas production (Table-1). Result shows similarities with the results reported for Pseudomonas (Sneha et al., 2012; Sadat et al., 2013). SO2-B culture showed similar results as SD2-A except citrate utilization test and TSI reactions. Cultures SD1-A and SO1-B were able to reduce nitrate, ferment glucose and sucrose. They showed positive results for catalase test and VP test. More confirmatory tests are needed to identify the isolate.

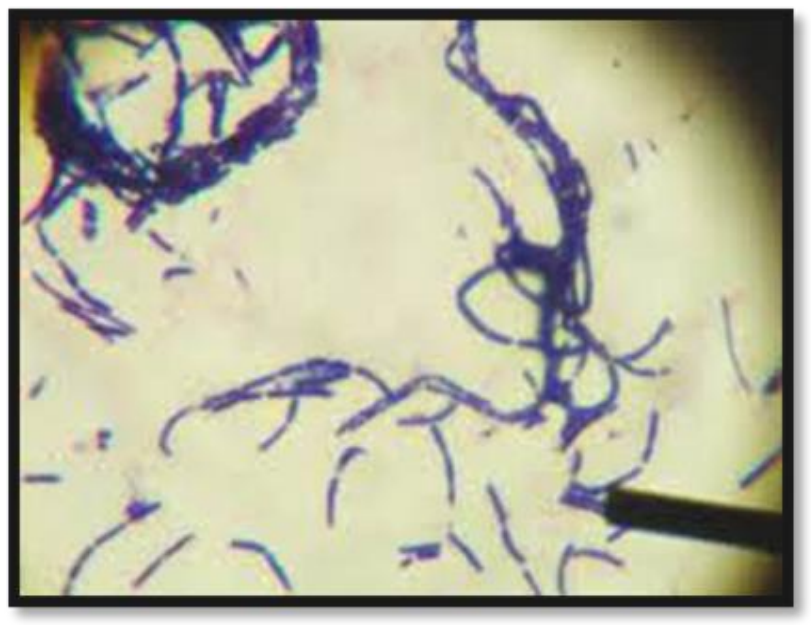

Figure 2 Gram staining of C5C

\section{Quantitative measurement of surface tension of fermented broth}

On the basis of hemolytic zone obtained on blood agar plate, cultures C5C, SD1A, SO1-B, SO2-A and SO2-B which gave excellent or good hemolytic activity were selected for further studies. All five selected cultures were studied further for the reduction of surface tension. Results are shown in Table 2. Culture C5C reduced surface tension of broth by $40.56 \mathrm{mN} / \mathrm{m}$ which was lowest compare to other four cultures. Mathiyzhagan et al., (2011) reported the surface tension reduction of cell free cultures broth ranging from $64.0 \mathrm{mN} / \mathrm{m}$ to $28 \mathrm{mN} / \mathrm{m}$ using organisms isolated from oil contaminated soil. Bacillus subtilis isolated from Kanchipuram reported to have surface activity $51.38 \mathrm{~nm}^{-1}$ (Ramesh et al., 2011). Similar results were also observed in the present study.
Table 2 Quantitative measurement of surface tension and surface activity of selected culture broth

\begin{tabular}{lcc}
\hline Cultures & Surface tension $\left[\mathbf{n m}^{-1}\right]$ & Surface activity $\left[\mathbf{n m}^{-1}\right]$ \\
\hline Control & $92.8 \times 10^{(-3)}$ & 00 \\
\hline SD1-A & $51.11 \times 10^{(-3)}$ & 41.69 \\
\hline SO1-B & $91.24 \times 10^{(-3)}$ & 1.56 \\
\hline SO2-A & $78.49 \times 10^{(-3)}$ & 14.31 \\
\hline SO2-B & $56.72 \times 10^{(-3)}$ & 36.08 \\
\hline C5C & $40.56 \times 10^{(-3)}$ & 51.78 \\
\hline
\end{tabular}

Cultures C5C, SO2-A and SD1-A were found to be good biosurfactant producers according to criteria demonstrated by Mulligan (2005). Amongst the isolates selected C5C showed highest surface activity and thus it was further studied for detail study.

\section{Production and extraction of biosurfactant from C5C (Bacillus species)}

Isolate $\mathrm{C} 5 \mathrm{C}$ was used for further studies on biosurfactant production by inoculating it in MSM medium (with $1 \%$ diesel as carbon source) at $37^{\circ} \mathrm{C}$ at 121 rpm for seven days. Isolate C5C produced $3.12 \mathrm{~g} / \mathrm{l}$ dry weight of biosurfactant Bacillus clausii $5 \mathrm{~B}$ produced $2.41 \mathrm{~g} / \mathrm{l}$ of biosurfactant in minimal medium with $1 \% \mathrm{w} / \mathrm{w}$ glucose as carbon source and ammonium chloride as nitrogen source (Aparna et al., 2012). Bacillus subtilis SPB1 produced $2.93( \pm 0.32) \mathrm{g} / 1$ of biosurfactant when media was incorporated with $15 \mathrm{~g} / \mathrm{l}$ of glucose, $6 \mathrm{~g} / \mathrm{l}$ of urea and $1 \mathrm{~g} / \mathrm{l}$ of $\mathrm{K}_{2} \mathrm{HPO}_{4}$ (Abdel-Mawgoud et al., 2008).

\section{pH and Temperature optimization}

Biosurfactant produced by $\mathrm{C} 5 \mathrm{C}$ gave maximum $\mathrm{E} 24 \%$ at $\mathrm{pH} 5$ and $30^{\circ} \mathrm{C}$ temperature in MSM medium with $1 \%$ diesel (Fig 2 and 3). $\mathrm{pH}$ optimization results showed that there was significant increase in emulsification in $\mathrm{pH}$ range 2 to 5 and as further increase in $\mathrm{pH}$ emulsification reduced. Similarly maximum E24\% was observed at $30^{\circ} \mathrm{C}$. After that with E24\% is positively decreases. Because of easy evaporation of diesel at higher temperature biosurfactant production might be decrease due to lack of carbon source under batch fermentation operate under shaking flask condition. Surfactin production from Bacillus subtilis DSM 3256 was reported to be highest at $6.75 \mathrm{pH}$ and $37.4^{\circ} \mathrm{C}$ temperature (Sen and Swaminathan, 1997). Iturine-A was produced maximally by Bacillus subtilis at $\mathrm{pH} 5.9-6.3$ and $25^{\circ} \mathrm{C}$ temperature (Mizumoto and Shoda, 2007). Bacillus megaterium produced maximum glycolipid at $\mathrm{pH} 8$ and $37^{\circ} \mathrm{C}$ under solid state fermentation (Thavasi et al., 2007).Similarly optimum condition for surfactin production form Bacillus subtilis BS5 was 6.5-6.7 pH and $30^{\circ} \mathrm{C}$ as reported by Abdel-Mawgoud et al., (2008). Penicillum chrysogenum SNP5 which showed increase in E24\% between 2 to $8 \mathrm{pH}$ range, while E24\% decreased between pH 8 to 12 (Gautam et al., 2014). 


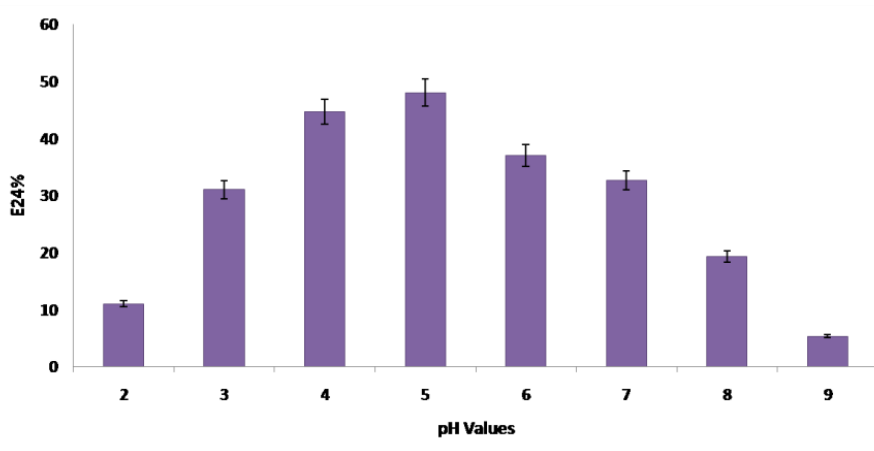

Figure $2 \mathrm{pH}$ optimization

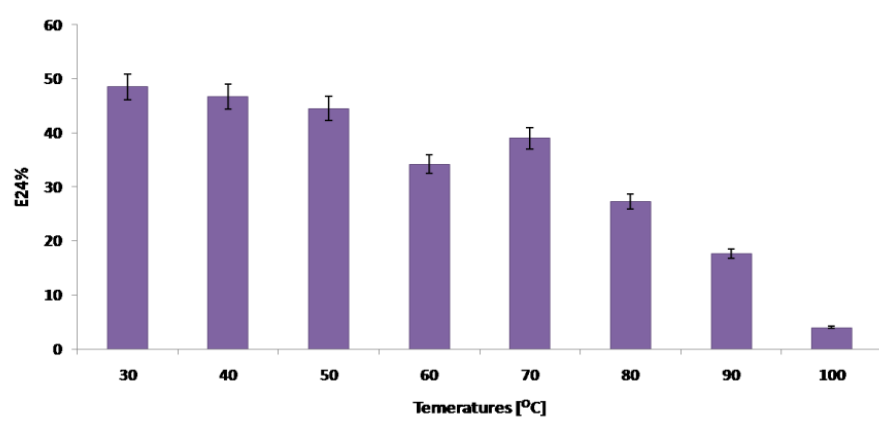

Figure 3 Temperature optimization

Characterization of biosurfactant by TLC

Biosurfactant produced from isolate $\mathrm{C} 5 \mathrm{C}$ was analyzed by Thin Layer Chromatography (TLC). As shown in Fig 4, a purple colour spot appearing on TLC ( $R f$ value 0.57$)$ suggested presence of polar lipid content in biosurfactant There was no colour development observed for amino acid or carbohydrate Similar result was observed by Aparna et al., (2012) that Bacillus clausii 5B biosurfactant produce red spot on silica gel plate. $\mathrm{R}_{f}$ value of biosurfactant was 0.51. Nishanthin et al., (2010) have reported strains BPB7 and BPB13 isolated from petrochemical waste soil produced biosurfactant which is glycolipid in nature. Biosurfactant from Arthrobacter strain is reported to be lipopeptides and lipoprotein in nature (Cipinvte et al., 2011).

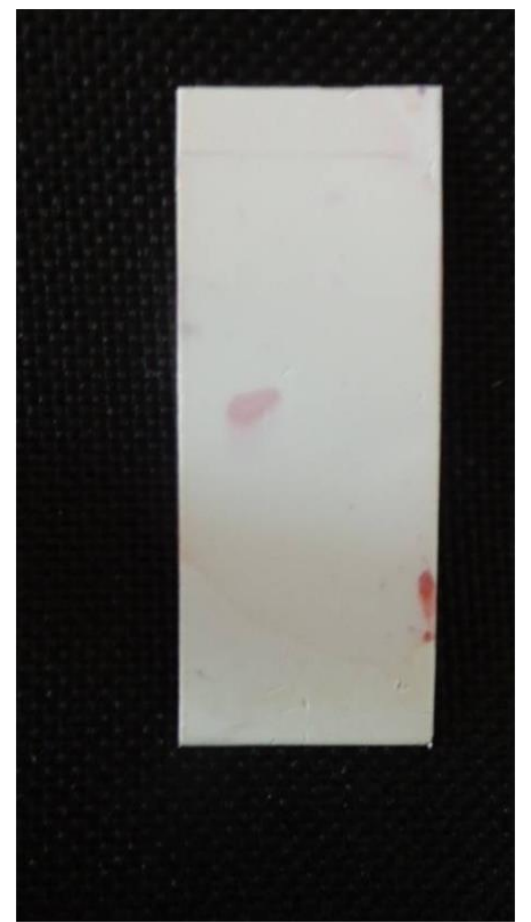

Figure 4 TLC analysis of biosurfactant

\section{CONCLUSIONS}

Thirty cultures were isolated from garage soil near Anand (Gujarat) region. They were characterized morphologically and biochemically. On the basis of screening techniques culture $\mathrm{C} 5 \mathrm{C}$ was found to be potential isolate for production of biosurfactant among thirty isolates. It was identified as Bacillus sp biochemically as it gave positive response for Voges Proskauer test, citrate utilization test nitrate test, starch utilization test and glucose fermentation test. Triple sugar ion test showed production of gas with acidic slant and alkaline butt reaction that confirm the Bacillus sp. Cultural conditions $\mathrm{pH}$ and temperature were also optimized for maximum production of biosurfactant. It produced $3.12 \mathrm{~g} / \mathrm{l}$ of dry precipitate of biosurfactant in MSM medium (pH 5) with $1 \%$ diesel at $30^{\circ} \mathrm{C} 121$ rpm. Further optimization of culture media and condition can be done. Structural characterization, indicate presence of polar lipid content in biosurfactant.

\section{REFERENCES}

ADBEl-MaWgoud, A. M., ABAulwaFA, M. M., Hassouna, N. A 2008. Optimization of surfacetin production by Bacillus subtilis isolated BS5. Applied Biochemistry and Biotechnology. 150, 305-325. http://dx.doi.org/10.1007/s12010-008-8155-x

ALI, S. R., CHOWDHARY, B. R., MONDAL, P., RAJAK, S. 2013. Screening and characterization of biosurfactant producing microorganism from natura environment. Journal of Natural Science and Research. 3 (13), 53-58.

ANANDRAJ, B., THIVKARAN, P. 2010. Isolation and production biosurfactant producing organism from oil spilled soil. Journal of Bioscience and Technology. $1(3), 120-126$

APARNA, A., SRINIKETHAN, G., HEGDE, S. 2012. Isolation, screening and production of biosurfactant by Bacillus Clausii 5B. Research in Biotechnology. 3(2), 40-56.

BATISTA, S. B., MOUNTEER, A. H., AMORIM, F. R., TOTOLA, M. R. 2006. Isolation and characterization of biosurfactant/bioemulsifier producing bacteria from petroleum contaminated sites. Bioresource Technology. 97, 868-875. http://dx.doi.org/10.1016/j.biortech.2005.04.020

CHANDER, C.R., LOHITNATH, T., KUMAR, D.J., KALAICHELVAN, P. T. 2012. Production and characterization of biosurfactant from Bacillus subtilis 441 and its evaluation to use as bio-emulsifier for food bio-preservative. Advances in Applied Science and Research. 3(3), 1827-1831.

CHANDRAN, P., DAS, N. 2011. Characterization of sophorolipid biosurfactant produced by yeast species grown on diesel oil. International Journal of Sciences and Nature. 2(1), 63-71

CIPINYTE, V., GRIGISKIS, S., SAPOKAITE, D., BASKYS, E. 2011 Production of biosurfactant by Arthrobacter spp N3: A hydrocarbon degrading bacteria (Proceeding of $8^{\text {th }}$ International Scientific and Practical Conference 1). 68-75. ISBN: 978-9984-44-070-5.

GAUTAM. G., MISHRA. V., VERMA. P., PANDEY. A., NEGI. S., 2014. A Cost effective strategy for production of biosurfactant from locally isolated Penicillium chrysogenum SNP5 and its applications. Journal of Bioprocessing and Biotechniques.4. 177. http://dx.doi.org/10.4172/2155-9821.1000177

KIM, P. I., BAI, H., BAU, D., CHUE, H., CHANG, S., KIM, Y., PARK, R., CHU, Y. T. 2004. Purification and characterization of lipopeptide produced by Bacillus thuringiensis CMB26. Journal of Applied Microbiology. 9, 7942-949. http://dx.doi.org/10.1111/j.1365-2672.2004.02356.x

MARCHANT, R., BANATH, I. M. 2012. Microbial biosurfactant: challenges and opportunities for future exploitation. Trends in Biotechnology 30 (11), 558565. http://dx.doi.org/10.1016/j.tibtech.2012.07.003

MATHIYAZHAGAN, N., DANASHEKAR, K., NATARAJAN, D. 2011 Amplification of biosurfactant producing gene (rhlB) from Pseudomonas aeruginosa isolate from oil contaminated soil. International Journal of Pharmaceutical and Biosciences. 2(1), 497-504.

MIZUMOTO, S., SHODA, M. 2007. Medium optimization of antifungal lipopeptide Iturine-A production by Bacillus subtilis in solid state fermentation by response surface methodology. Applied Microbiology and Biotechnology. 76,101-108. http://dx.doi.org/10.1007/s00253-007-0994-9

MNIF, I., CHAABONI-ELLOUZE, S., GHRIBI, D. 2012. Optimizations of the nutritional parameter for enhanced production of Bacillus subtilis SPB1 biosurfactant in submerge culture using response surface methodology. $\begin{array}{lll}\text { Biotechnology Research } & \text { International. }\end{array}$ http://dx.doi.org/10.1155/2012/795430

MULLIGAN, C.N. 2005. Environmental applications for biosurfactant. Environmental $\quad$ Pollution. 133,198 . http://dx.doi.org/10.1016/j.envpol.2004.06.009

NASR, S., SODI, M. R., MEHRINA, M. R., SARRAFZADEH M. H. 2009 Characterization of novel biosurfactant producing Bacillus spp. isolated from petroleum contaminated soil. Iranian Journal of Microbiology. 1(2), 54-61.

NISHANTHIN, R., KUMARAN, S., PALANI, P., CHELLARAM, C., PREMANAND, T., KANNAN, V. 2010. Screening of biosurfactant from hydrocarbon degrading bacteria. Journal of Ecobiotechnology. 2(5), 47-53.

RAMESH. B., SURESH. G., RAVICHANDRAN. N., VIJAIYANSIVA. G., 2011. Screening and isolation of potential biosurfactant producing Bacillus subtilis CS14 from contaminated soil sample of Kanchipuram, India. Journal of Research in Biology. 2: 140-147

RUFINO, R. D., LUNA, J. M., TOKAKI, G. M., SARUBBO, L.A. 2014 Characterization and properties of the biosurfactant produced by Candida 
lipolytica UCP 0988. Electronic Journal of Biotechnology. 17 (1), 34-38. http://dx.doi.org/10.1016/j.ejbt.2013.12.006

SADAT, A., ROOZBEHANI, B., JAAFARZADEH, N, HAGHIGHIFARD. 2013. Production of biosurfactant from oil sludge using isolated Pseudomonas. Journal of Environmental Friendly Processes. 1(2), 22-25.

SATPUTE, S. K., BANPURKAR, A. G., DHAKEPHALKAR, P. K., BANATH, I. M., CHOPDE, B. A. 2010. Methods of investigation biosurfactant and bioemulsifier: A review. Critical Reviews in Biotechnology. 1-18. http://dx.doi.org/10.3109/07388550903427280

SEN, R., SWAMINATHAN, T.1997. Application of response-surface methodology to evaluate the optimum environmental conditions for enhanced production of surfactin. Applied Microbiology and Biotechnology. 2(5), 47-53. http://dx.doi.org/ 10.1007/s002530050940

SNEHA, K. S., PADMAPRIYA, B., RAJESWARI, T. 2012. Isolation and screening of biosurfactant produced by Pseudomonas aeruginosa from oil spilled soils. International Journal of Pharmaceutical Biology Archives. 3(2), 312-325.

THAVASI, B., JAYALAKSHMI, S., BALASUBRAMANIAN, BANATH, I. M. 2007. Production and characterization of glycolipid biosurfactant from Bacillus megaterium using economical cheaper sources. World Journal of Microbiology and Biotechnology. 24, 917-925. http://dx.doi.org/10.1007/s11274-007-9609-y

TUCKER, W.B. 1938. Surface tension by pendant drop. Massachusetts institute of technology, Massachusetts.

VARJANI, S. J., RANA, D. P., BATEJ, S., SHARMA, M. C., UPASANI, V. N. 2014. Screening and identification of biosurfactant (bioemulsifier) producing bacteria from crude oil contaminated sites of Gujarat India. International Journal of Innovative Research in Science, Engineering and Technology. 31(2), 312-325.

YIN, H., QIANG, J., JIA, Y., YE, J., PENG, H., GIN, H., ZANG, N., HE, B 2009. Characterization of biosurfactant produced by Pseudomonas aeruginosa S6 isolated from oil contaminating waste water. Process Biochemistry. 44, 303-308. http://dx.doi.org/10.1016/j.procbio.2008.11.003

YOUSSEF, N.H., EDUNCAN, K., NAGLE, D.P., SAVAG, K.N., KNAPP, R.M.

AND MCINEMEY, M. J.2014. Comparison of methods to detect biosurfactant produced by diverse microorganism. Journal of Microbiology Methods. 56, 339347.http://dx.doi.org/10.1016/j.mimet.2003.11.001 